\title{
QUALITY-ASSURANCE PLAN \\ FOR WATER-RESOURCES ACTIVITIES OF THE \\ U.S. GEOLOGICAL SURVEY IN MONTANA--1995
}

Revised

By Joe A. Moreland

U.S. GEOLOGICAL SURVEY

Open-File Report 91-194

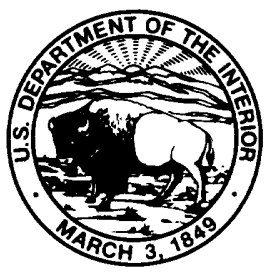




\title{
U.S. DEPARTMENT OF THE INTERIOR BRUCE BABBITT, Secretary
}

\author{
U.S. GEOLOGICAL SURVEY
}

Gordon P. Eaton, Director Open-File Reports Section Box 25286, Mail Stop 517 Denver Federal Center Denver, CO 80225-0286 
QUALITY-ASSURANCE PLAN FOR THE MONTANA DISTRICT

APPROVED BY:

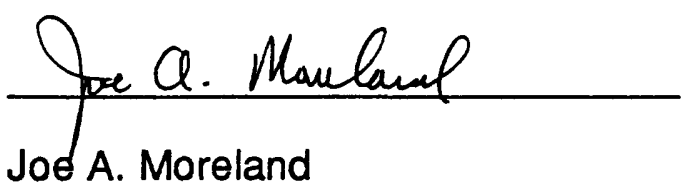

Joe A. Moreland

Chief, Montana District

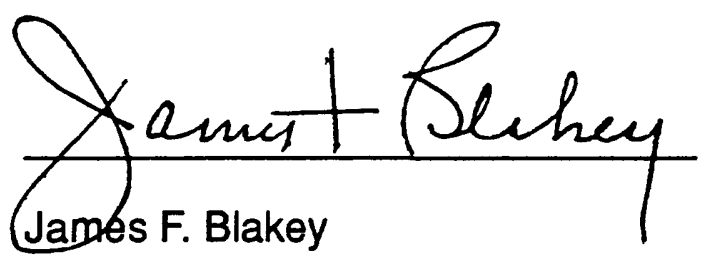

Regional Hydrologist, Central Region
$2 / 17 / 95$

Date

$2 / 17 / 95$

Date

iii

(Every follow is) 


\section{CONTENTS}

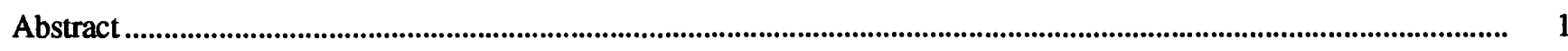

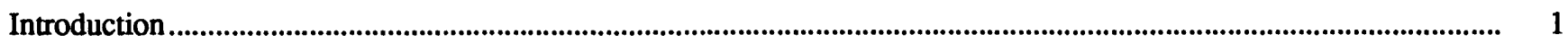

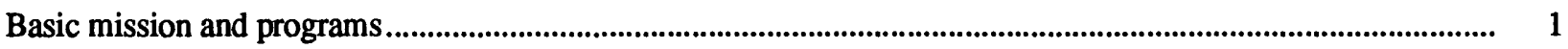

U.S. Geological Survey........................................................................................................................ 1

Water Resources Division .............................................................................................................. 2

Need for quality assurance .......................................................................................................................................... 3

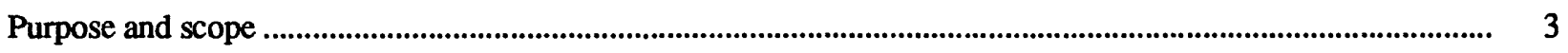

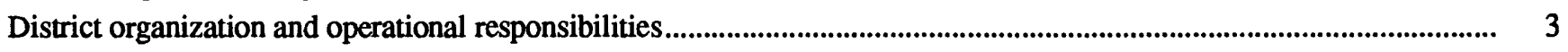

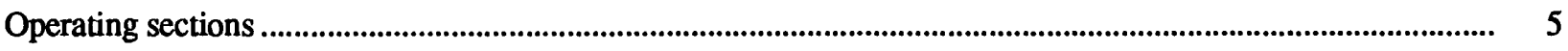

Hydrologic Surveillance and Analysis Section...................................................................................... 5

International Waters Section ................................................................................................................... 9

Hydrologic Investigations Section ......................................................................................................... 9

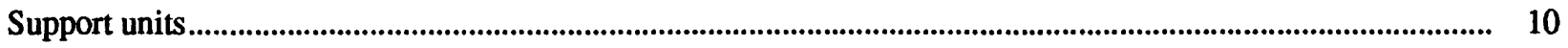

Administrative Services Unit .................................................................................................................. 10

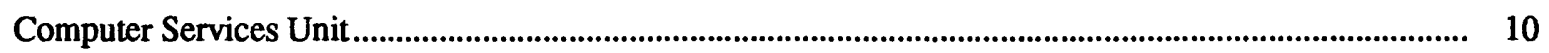

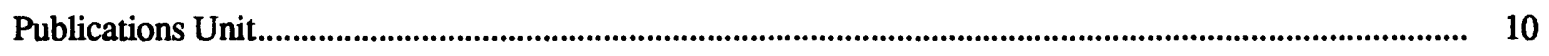

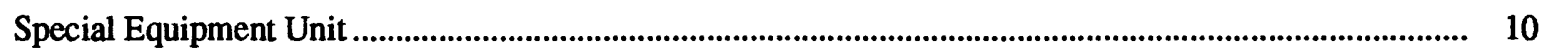

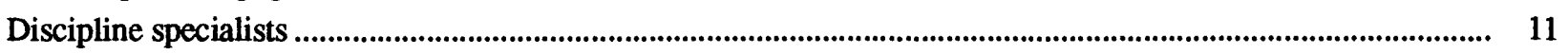

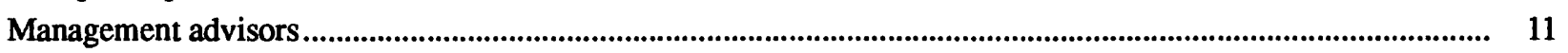

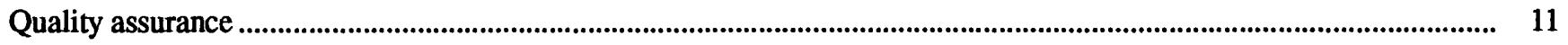

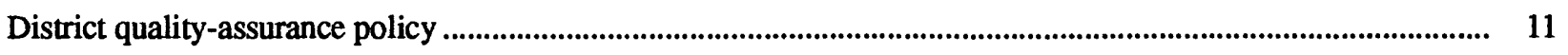

District functions and quality-assurance responsibliities .......................................................................... 12

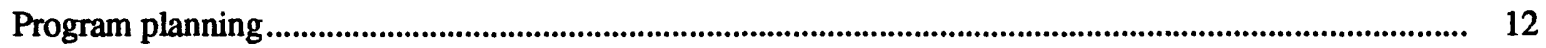

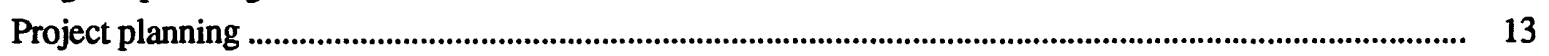

Project implementation ........................................................................................................................ 13

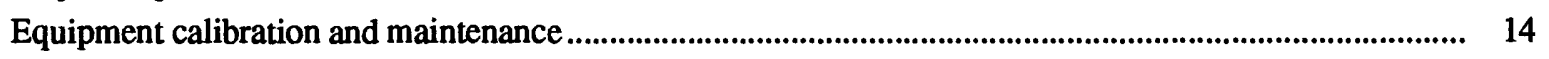

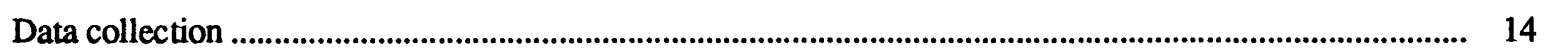

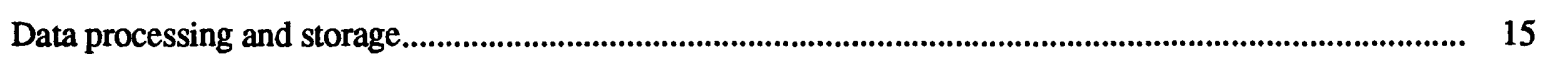

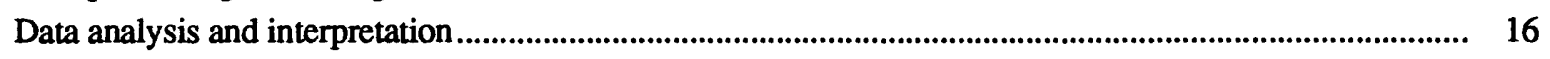

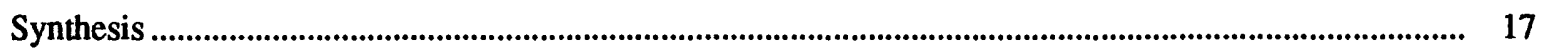

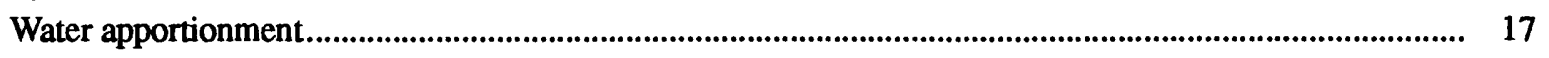

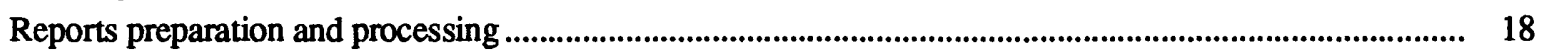

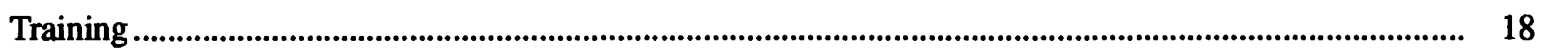

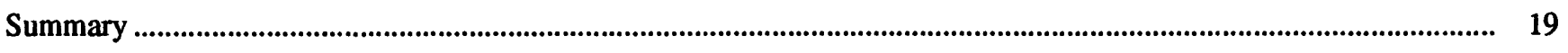

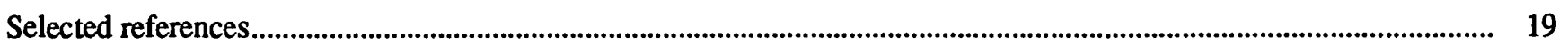

\section{ILLUSTRATIONS}

Figure 1. Organization chart of the Water Resources Division of the U.S. Geological Survey, 1995 ........................... 4

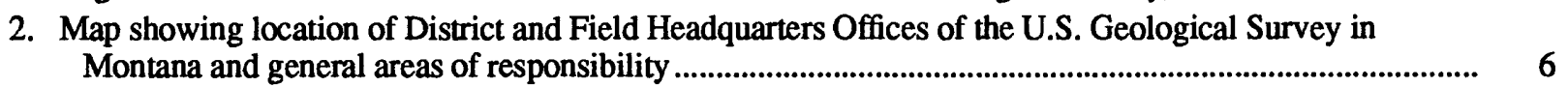

3. Organization chart of the Montana District, 1995 ............................................................................. 8 


\section{QUALITY-ASSURANCE PLAN \\ FOR WATER-RESOURCES ACTIVITIES OF THE U.S. GEOLOGICAL SURVEY IN MONTANA-1995}

by Joe A. Moreland

\section{Abstract}

As the Nation's principal earth-science information agency, the U.S. Geological Survey has developed a worldwide reputation for collecting accurate data and producing factual and impartial interpretive reports. To ensure continued confidence in its products, the Water Resources Division of the U.S. Geological Survey has implemented a policy that all scientific work by or for the Division is required to be performed in accordance with a centrally managed quality-assurance program. This report establishes and documents a formal policy for current (1995) quality assurance within the Montana District of the U.S. Geological Survey. Quality assurance is formalized by describing District organization and operational responsibilities, documenting the District qualityassurance policy, and describing District functions and the quality-assurance responsibilities for performing those functions.

The District conducts its work through offices in Helena, Billings, Kalispell, and Fort Peck. Data-collection programs and interpretive studies are conducted by three operating sections and four support units. Discipline specialists provide technical advice and assistance to the District and to chiefs of various projects. Management advisors provide guidance on various personnel issues and support functions.

The District's quality-assurance plan consists of an overall policy that provides a framework for defining the precision and bias of collected data. That plan is supported by a series of quality-assurance policy statements that describe responsibilities for specific functional elements of the District's program. The functional elements described are program planning, project planning, project implementation, equipment calibration and maintenance, data collection, data pro- cessing and storage, data analysis and interpretation, synthesis, water apportionment, reports preparation and processing, and training. Activities of the District are systematically conducted under a hierarchy of supervision and management that is designed to ensure conformance with Division goals on quality assurance.

The District quality-assurance plan does not describe detailed technical activities that are commonly termed "quality-control procedures." Instead, it focuses on current (1995) policies, functions, and responsibilities that are implemented at the management level. Contents of the plan will be reviewed annually and updated as personnel and programs change.

\section{INTRODUCTION}

The U.S. Geological Survey has collected and disseminated information about the quality and quantity of water in Montana's streams, lakes, and aquifers for more than a century. Through cooperative and collaborative programs with local, State, and other Federal agencies, the Montana District of the U.S. Geological Survey has monitored streamflow at hundreds of sites throughout the State and has investigated the occurrence, availability, and quality of water in numerous study areas. Information obtained from data-collection programs, investigative studies, and research efforts has been made available to the public, water-resource managers, regulators, and developers through annual data reports, formal published reports, and open-file releases.

\section{Basic Mission and Programs}

\section{U.S. Geological Survey}

The U.S. Geological Survey was established by an act of Congress on March 3,1879, to provide a permanent Federal agency to conduct the systematic and 
scientific "classification of the public lands, and examination of the geological structure, mineral resources, and products of national domain." An integral part of that original mission includes publishing and disseminating the earth-science information needed to understand, plan the use of, and manage the Nation's energy, land, mineral, and water resources.

Since 1879, the research and fact-finding role of the U.S. Geological Survey has grown and has been modified to meet the changing needs of the Nation it serves. As part of the evolution, the U.S. Geological Survey has become the Federal Government's largest earth-science research agency, the Nation's largest civilian mapmaking agency, the primary source of data on the Nation's surface- and ground-water resources, and the employer of the largest number of professional earth scientists in the Nation. Today's programs serve a diversity of needs and users. Programs include:

- Conducting detailed assessments of the energy and mineral potential of land and offshore areas.

- Investigating and issuing warnings of earthquakes, volcanic eruptions, landslides, and other geologic and hydrologic hazards.

- Conducting research on the geologic structure of land and offshore areas.

- Studying the geologic features, structures, processes, and history of the other planets of our solar system.

- Conducting topographic surveys and preparing topographic and thematic maps and related cartographic products.

- Developing and producing digital cartographic data bases and products.

- Collecting data on a routine basis to determine the quantity, quality, and use of surface and ground water.

- Conducting water-resource appraisals to describe the consequences of alternative plans for developing land and water resources.

- Conducting research in hydraulics and hydrology, and coordinating all Federal water-data acquisition.

- Using remotely sensed data to develop new cartographic, geologic, and hydrologic research techniques for natural-resources planning and management.
- Providing earth-science information through an extensive publications program and a network of public access points.

Along with its continuing commitment to meet the growing and changing earth-science needs of the Nation, the U.S. Geological Survey remains dedicated to its original mission of collecting, analyzing, interpreting, publishing, and disseminating information about the natural resources of the Nation--providing "Earth science in the public service."

\section{Water Resources Division}

The mission of the Water Resources Division is to provide the hydrologic information and understanding needed for the optimum utilization and management of the Nation's water resources for the overall benefit of the people of the United States. This mission is accomplished, in large part, through cooperation with other Federal and nonfederal agencies, by:

- Collecting, on a systematic basis, data needed for the continuing determination and evaluation of the quantity, quality, and use of the Nation's water resources.

- Conducting analytical and interpretive water-resource appraisals describing the occurrence, availability, and physical, chemical, and biological characteristics of surface and ground water.

- Conducting supportive basic and problem-oriented research in hydraulics, hydrology, and related fields of science to improve the scientific basis for investigations and measurement techniques and to understand hydrologic systems sufficiently well to quantitatively predict their response to stress, either natural or manmade.

- Disseminating water data and the results of investigations and research through reports, maps, computerized information services, and other forms of public releases.

- Coordinating the activities of Federal agencies in the acquisition of water data for streams, lakes, reservoirs, estuaries, and ground water.

- Providing scientific and technical assistance in hydrologic fields to other Federal, State, and local agencies, to licensees of the Federal Energy Regulatory Commission, and to inter- 
national agencies on behalf of the U.S. Department of State.

- Acquiring, developing, and disseminating information on water-related natural hazards such as droughts, floods, landslides, land subsidence, mudflows, and volcanoes.

- Administering the provisions of the Water Resources Research Act of 1984, which includes the State Water Resources Research Institutes and the Research Grants and Contracts programs.

- Supporting the provisions of the National Environmental Policy Act of 1969 and managing Geological Survey natural-resource surveys in response to the Comprehensive Environmental Response, Compensation, and Liability Act (Superfund Act) of 1980 and its amendments.

\section{Need for Quallty Assurance}

As the Nation's principal earth-science information agency, the U.S. Geological Survey has developed a worldwide reputation for collecting accurate data and producing factual and impartial interpretive reports. Methodologies for data collection and analysis developed by the U.S. Geological Survey have become standard techniques that are used by numerous Federal, State, and local agencies and private enterprises. The stringent standards of professional conduct, meticulous attention to detail, and thorough review that characterize the routine activities of the U.S. Geological Survey have given users of our products a sense of confidence and trust in the accuracy and scientific validity of our work. However, as competition for the Nation's finite water supply intensifies, programs to manage, protect, develop, and regulate the resource have become increasingly contentious. Thus, the products of our data collection and investigative programs are increasingly scrutinized. As a result, the users of our products are now expecting, and in some instances demanding, that U.S. Geological Survey programs be conducted in a manner that provides a measure of the precision and the bias of the results.

In response to those expectations and demands, the Water Resources Division has implemented a program designed to ensure that all scientific work performed by or for the Division is conducted in accordance with a centrally managed quality-assurance program. The responsibility for the program has been assigned to the Office of the Assistant Chief Hydrologist for Program Coordination and Technical Support (fig. 1). That office has established the Branch of Technical Development and Quality Systems (formerly the Branch of Quality Assurance) to develop, coordinate, and implement the quality-assurance program. As a part of that program, each District office in the Water Resources Division is required to prepare a written District Quality-Assurance Plan covering all elements of scientific work conducted by or for the office.

\section{Purpose and Scope}

This report establishes and documents a formal policy for the conduct of quality assurance within the Montana District of the U.S. Geological Survey. Quality assurance is formalized by:

- Describing the District organization and operational responsibilities.

- Documenting the District quality-assurance policy.

- Describing the District functions and qualityassurance responsibilities for performing those functions.

Included in this report are descriptions of the quality-assurance policies and responsibilities relating to the scientific activities of the District. The policies and responsibilities are presented by functional elements of the District's hydrologic programs and apply to work performed by the District or contract personnel. This report does not describe detailed technical activities that are commonly termed "quality-control procedures." Those activities are described in referenced literature, work plans, District and Water Resources Division memorandums, and field manuals. Instead, this report describes current (1995) policies, functions, and responsibilities that are implemented at the management level.

Contents of this report will be reviewed annually. As personnel and programs change, the report will be revised.

\section{DISTRICT ORGANIZATION AND OPERATIONAL RESPONSIBILITIES}

The Montana District conducts its hydrologic work through a District Office in Helena and Field 


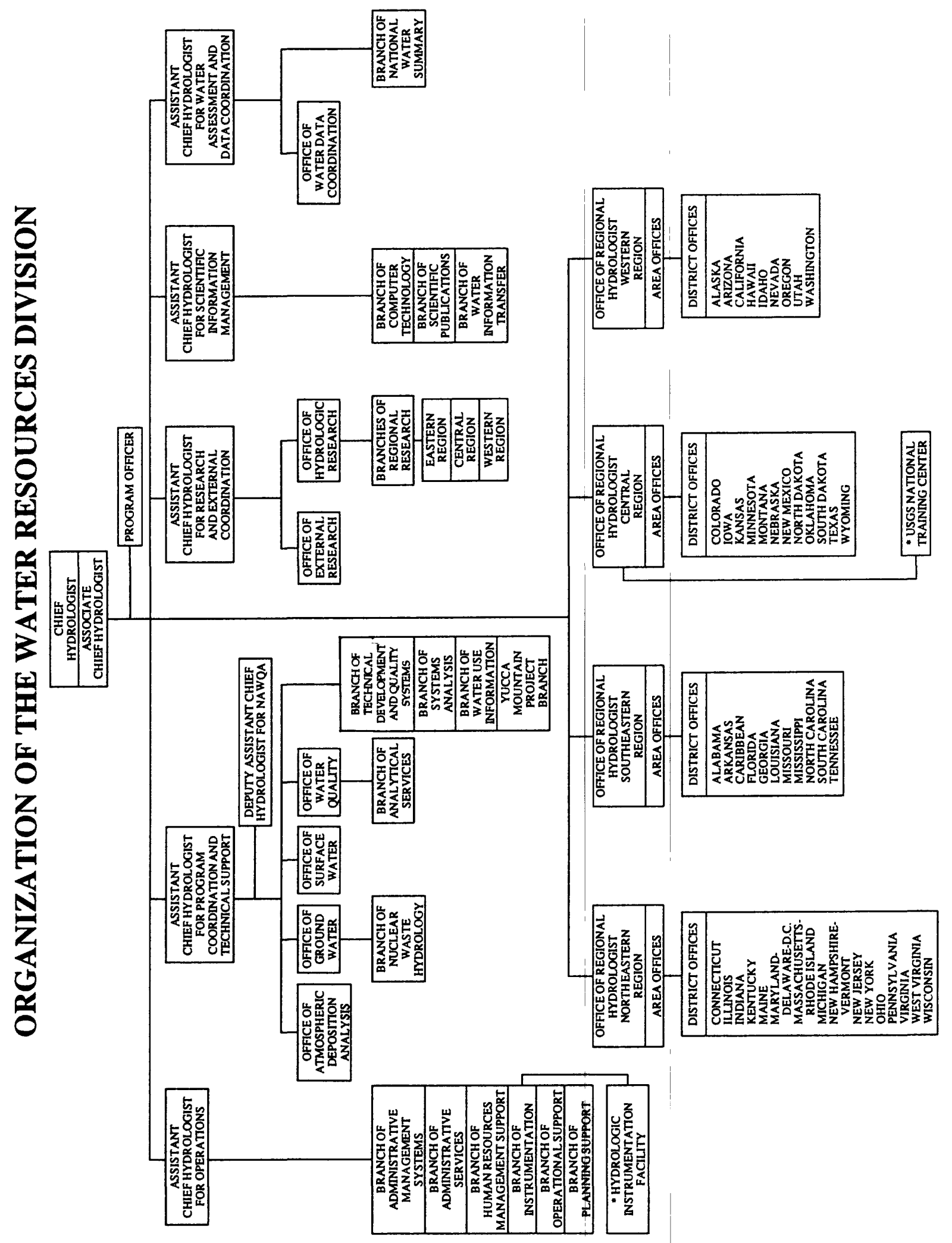

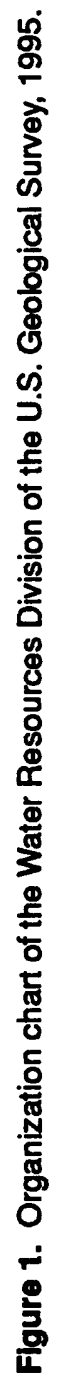


Headquarters in Helena, Billings, Kalispell, and Fort Peck (fig. 2). The District employs about 56 people to work on about 30 funded projects. The principal mission of the District is to investigate the occurrence, quantity, quality, distribution, and movement of surface and ground water in Montana.

Hydrologic data-collection programs and interpretive studies in Montana are conducted by three operating sections (Hydrologic Surveillance and Analysis Section, International Waters Section, and Hydrologic Investigations Section) and four support units (Administrative Services Unit, Computer Services Unit, Publications Unit, and Special Equipment Unit) (fig. 3). Discipline specialists provide technical expertise to the management staff, and selected individuals serve as management advisors on various personnel and administrative matters. The operating sections are responsible for implementation and execution of District projects. The support units and advisory groups provide services and advice to the Office of the District Chief (Joe A. Moreland) and the operating sections.

\section{Operating Sections}

\section{Hydrologic Surveiliance and Analysis Section}

The Hydrologic Surveillance and Analysis Section (directed by Ronald R. Shields) is responsible for designing, constructing, operating, and maintaining the hydrologic-data networks in the State. It also is responsible for analyzing hydrologic data from the State network, reviewing and processing of data, preparing water-resources data for the annual water-data report, and providing quality assurance in the collection of hydrologic data. The Section supervisor is responsible for quality assurance of data collected, processed, published, and stored by the Section.

Field Headquarters are responsible for data collection of the Section. The offices are directed by the following individuals:

Stephen V. Lynn ................ Helena Field Headquarters
Lawrence A. Merritt......... Billings Field Headquarters
Raymond J. Weinberg ....... Kalispell Field Headquarters
John J. French .................... Fort Peck Field Headquarters

Water-quality data are collected by personnel in each Field Headquarters. A hydrologic technician in each office has been designated to provide qualityassurance oversight of water-quality data-collection activities including calibration and maintenance of field instruments, maintenance of mobile field laboratories, collection of samples, preparation of field and laboratory forms, training of contract observers, and office review of field analyses. The Lead WaterQuality Technicians in the Field Headquarters in Helena and Billings are also responsible for reviewing laboratory analyses. The Lead Water-Quality Technicians for the offices are:

Philip L. Karper. Helena Field Headquarters Bruce M. Bochy ................ Billings Field Headquarters Raymond J. Weinberg ........ Kalispell Field Headquarters Michael R. Johnson ............ Fort Peck Field Headquarters

The Environmental Sciences Unit (directed by John $\mathrm{H}$. Lambing) is responsible for planning, overseeing, and reviewing the collection of water-quality data in the District. The water-quality monitoring programs include collection of chemical and physical data from streams, lakes, and reservoirs. The Unit is responsible for reviewing and approving temperature, specific-conductance, organic and inorganic chemical-constituent, and suspended-sediment records. Quality assurance of temperature, specific-conductance, and organic and inorganic chemical-constituent data and suspended-sediment records is overseen by John H. Lambing, Water-Quality and Sediment Specialist.

The Environmental Sciences Unit, in addition to having responsibility for reviewing and approving the water-quality records, is responsible for conducting water-quality oriented investigations including analysis of trends, documenting water-quality problems in selected areas, and assessing water-quality conditions. Project chiefs of these investigations coordinate project activities with the Chief of the Hydrologic Investigations Section.

The Environmental Sciences Unit is responsible for operating the District Water-Quality Laboratory. Personnel assigned to the Laboratory routinely measure water-quality characteristics, including suspended-sediment concentrations, and perform laboratory analyses of atmospheric-precipitation samples. John $\mathrm{H}$. Lambing is responsible for quality assurance of the Laboratory and Kent A. Dodge is responsible for quality assurance of sediment analyses.

The Laboratory serves as the supply center for Field Headquarters for water-quality monitoring equipment, instruments, and supplies. Laboratory personnel prepare and distribute standard solutions and reagents for quality control and calibration checks of field instruments. Kent A. Dodge performs quality-control checks of water-quality equipment and instruments before they are distributed to field personnel.

The Data Management Unit (directed by Melvin K. White) is responsible for maintaining central files of data collected in the District, reviewing streamflow and 


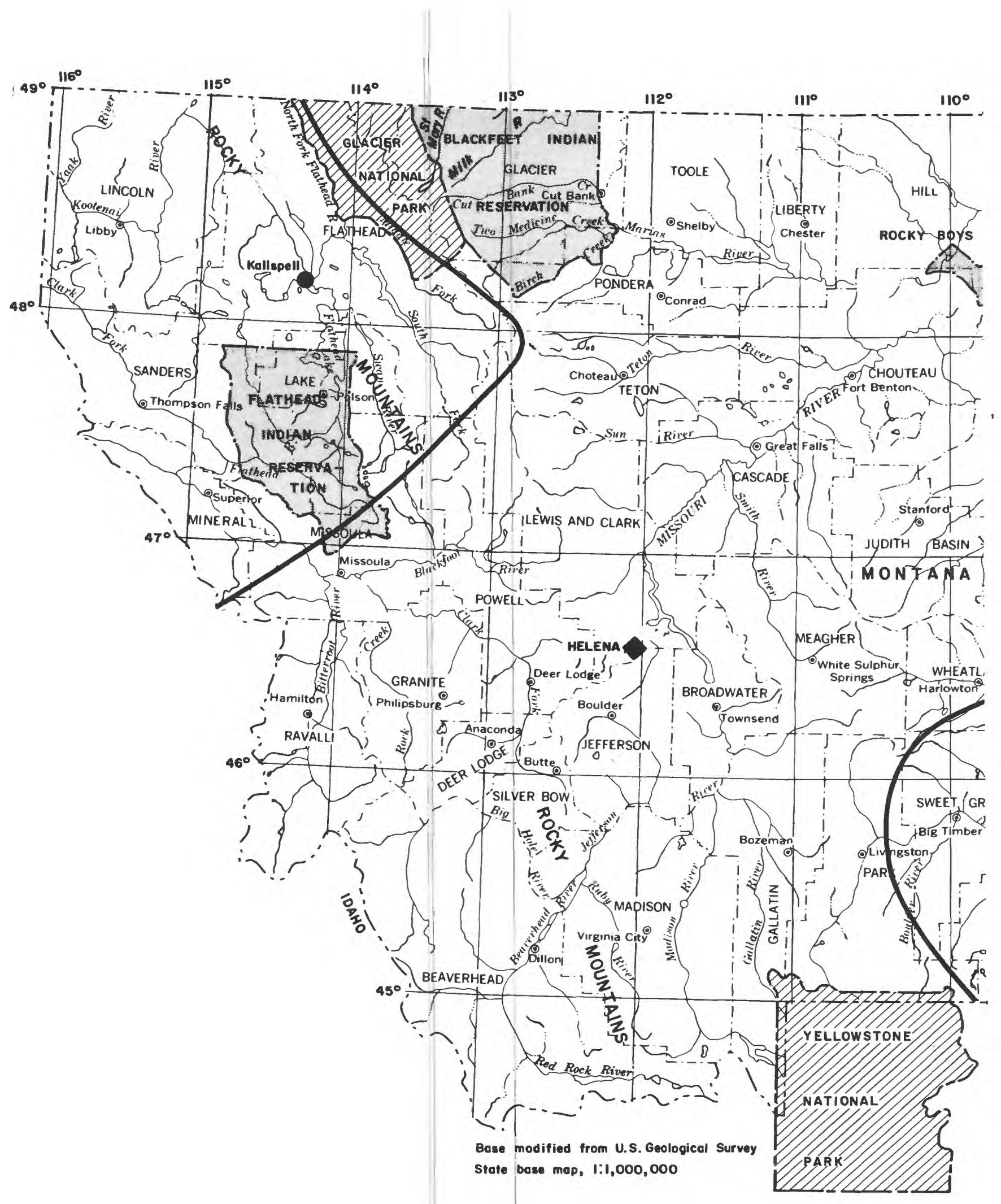

Flgure 2. Location of District and Field Headquarters Offices of the 


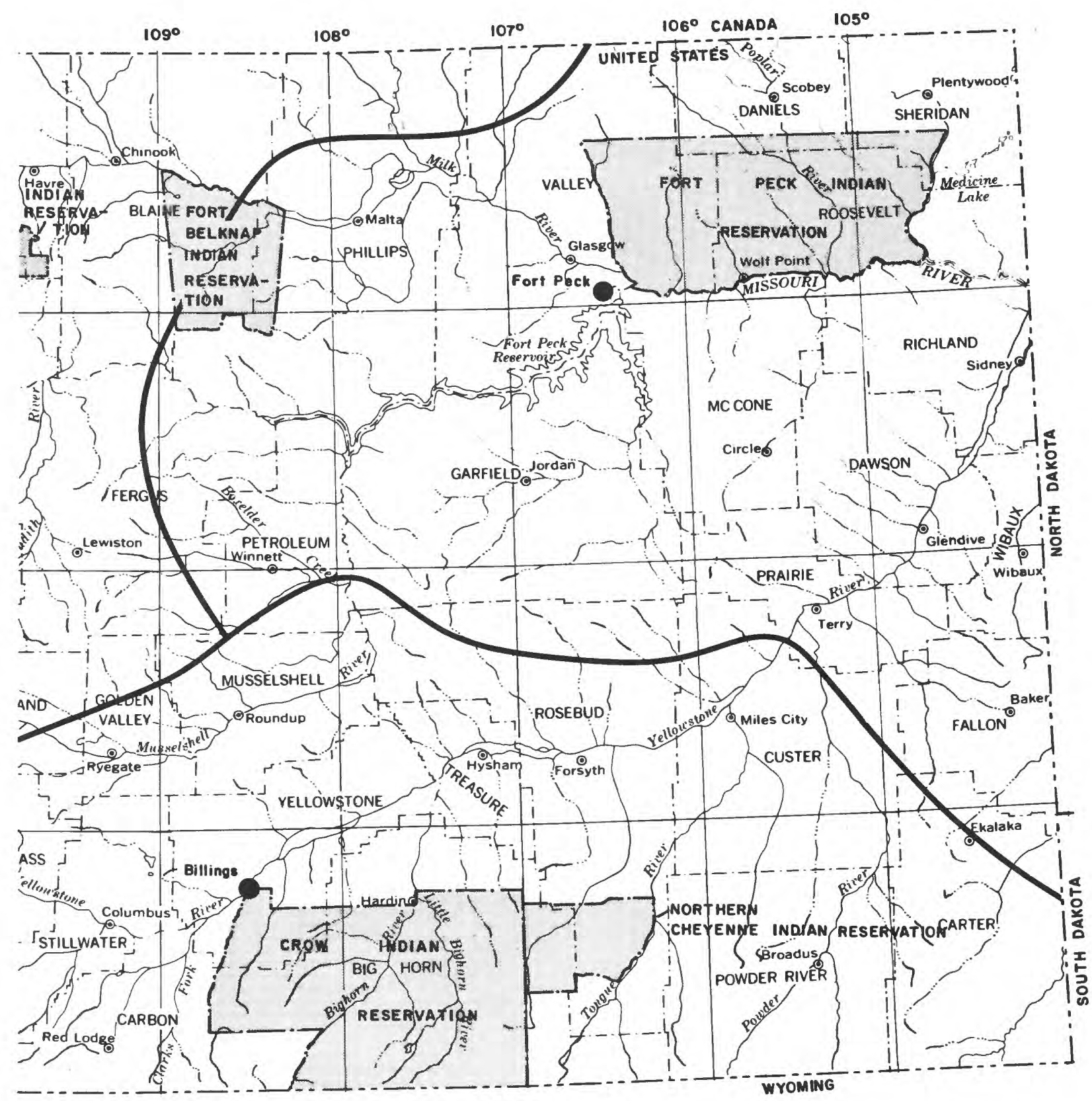

EXPLANATION

- District office (Helena)

- Field headquarters (Heleno,

Billings, Fort Peck, Kolispell)

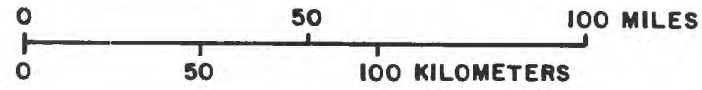

BOUNDARY FOR AREA OF

OFFICE RESPONSIBILITY

\section{U.S. Geological Survey in Montana and general areas of responsibility.}




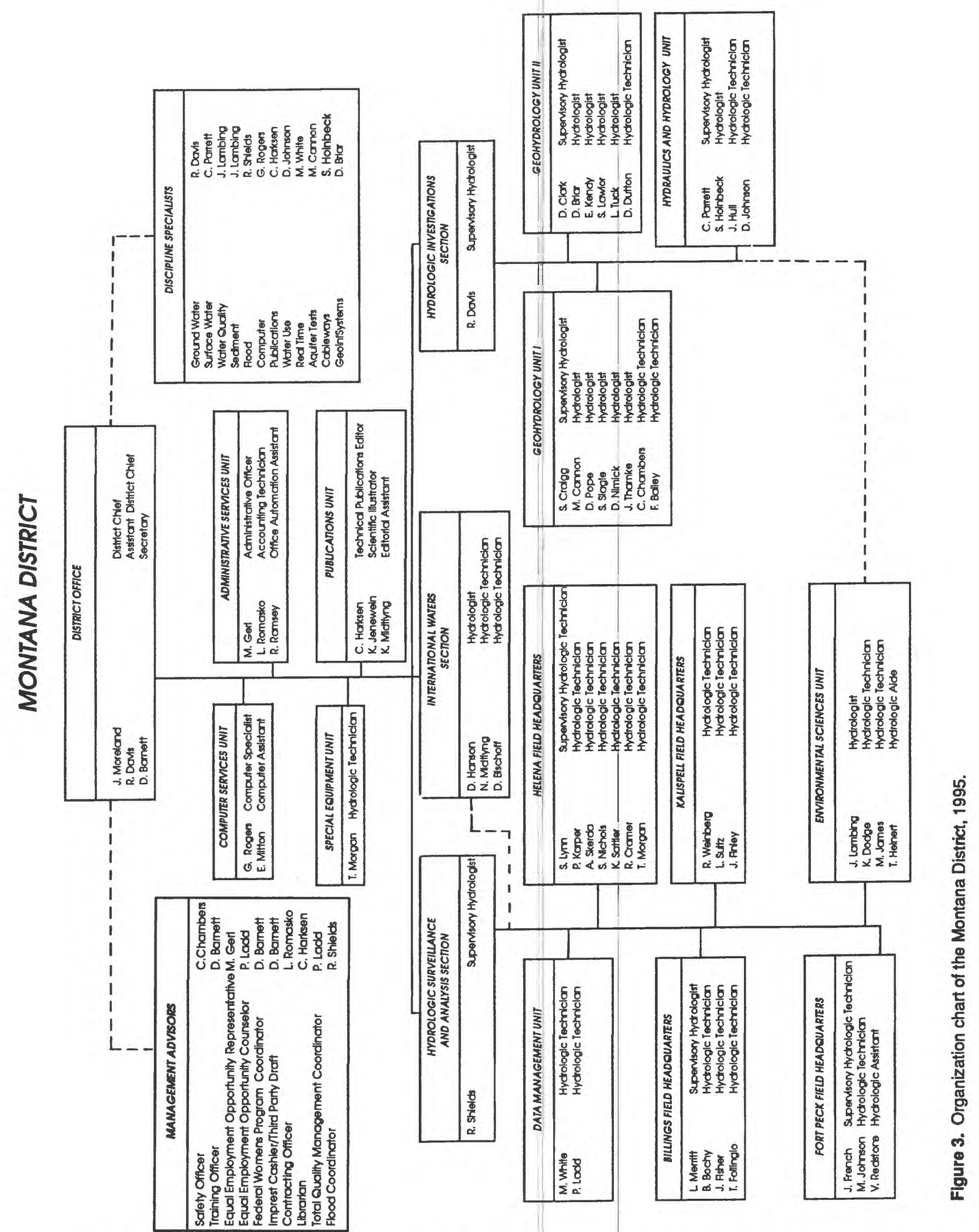


water-quality records, and preparing data for publication in the annual water-data report. Unit personnel also enter and store approved records in District and national computer data bases.

\section{International Waters Sectlon}

The International Waters Section is responsible for apportioning the water of the St. Mary and Milk Rivers in cooperation with the Water Survey of Canada as directed by the Boundary Waters Treaty of 1909 and the International Joint Commission Order of 1921. This apportionment involves operating 32 streamflowgaging stations and 7 reservoir-gaging stations; collecting data for several evaporation stations, 9 small reservoirs, and more than 300 minor diversions; computing streamflows, reservoir contents, and natural flows; and disseminating information to ensure the delivery of water entitlements to the United States and Canada.

Collection and computation of streamflow records, determination of natural flow, computation of entitlements to the United States and Canada, and calculation of excess or deficit deliveries are reviewed by David B. Hanson. Streamflow records and apportionment calculations are exchanged with Canadian counterparts, differences are reconciled, and final results are submitted for approval to Joe A. Moreland, the Field Representative for the Accredited Officer for the United States, St. Mary-Milk River Treaty. Quality assurance of work performed by the Section is controlled by detailed instructions on operation of international stations and apportionment procedures (U.S. Geological Survey, 1985). Approval of results by Joe A. Moreland documents adherence to guidelines. The Section is responsible for preparing records and computations for an annual report to the International Joint Commission. The Section is also responsible for preparing a summary of hydrologic conditions and apportionment activities with Canadian counterparts for inclusion in the annual report.

\section{Hydrologic investigations Section}

The Hydrologic Investigations Section (directed by Robert E. Davis) is responsible for planning, conducting, and reporting on multidiscipline waterresources projects. These investigations involve ground-water hydraulics and mathematical modeling of aquifer systems, hydraulic effects of manmade structures, magnitude and frequency of floods and droughts, assessment of surface-water availability and water use, and assessment or estimation of natural or anthropogenic effects on the quality of water in hydrologic systems.
Quality assurance of work performed by the Section is controlled by several District policies relating to project planning, project implementation, data collection, data analysis and interpretation, synthesis, and reports preparation and processing. Each project chief conducts investigations in accordance with District quality-assurance policies. The Section supervisor monitors all phases of project activities to ensure compliance with specific policies.

The Section is composed of three teams of hydrologists and technical support personnel. Geohydrology Units I and II personnel conduct studies related to ground water. Hydraulics and Hydrology Unit personnel conduct studies related to surface-water hydraulics, hydrology, and water use. The Units have overlapping responsibilities on many interdisciplinary projects. Personnel assigned to the Environmental Sciences Unit of the Hydrologic Surveillance and Analysis Section also conduct hydrologic studies related to surface-water quality that are coordinated through the Hydrologic Investigations Section.

Geohydrology Unit I is directed by Steven D. Craigg, who is responsible for the Unit's compliance with quality-assurance policies. Project chiefs in the Unit conduct ground-water-related projects and prepare reports for publication. The Unit is responsible for maintaining the Ground-Water Site Inventory (GWSI) file. Information from all wells inventoried by District personnel as part of ongoing projects is entered into the national GWSI data base. Joanna N. Thamke is responsible for maintaining the GWSI data base. The Unit is also responsible for collecting, processing, and storing water-level data obtained through various District activities. Clarence L. Chambers is responsible for reviewing, approving, and entering these data into District and national data bases. Aquifer tests conducted by District personnel are reviewed and approved by Michael R. Cannon before results are used in studies or published in reports. Water-quality data are reviewed by the Chief, Hydrologic Investigations Section and the District Water-Quality Specialist.

Geohydrology Unit II is directed by David W. Clark, who is responsible for the Unit's compliance with quality-assurance policies. Unit personnel conduct studies of ground-water systems in Montana and parts of Idaho and prepare reports for publication. The Unit is responsible for compiling and maintaining information on geology, aquifer properties, groundwater levels, ground-water chemistry, and related hydrologic data for ground-water basins. Data are stored in geographic information system (GIS) data files for use in interpretive studies. The GIS data files are developed in accordance with all Division policies 
issued on the subject. David W. Briar is responsible for monitoring GIS data bases.

The Hydraulics and Hydrology Unit is directed by Charles Parrett, who is responsible for the Unit's compliance with quality-assurance policies. The Unit is responsible for reviewing and approving indirect streamflow measurements performed by personnel in the Field Headquarters. Project chiefs in the Unit conduct projects related to surface water and water use and prepare reports for publication. Unit personnel also review and approve crest-stage gage records and computations from the Field Headquarters. The Unit is responsible for compiling and maintaining information on peak flows and basin characteristics and collecting and storing water-use data. James A. Hull is responsible for maintaining the crest-stage gage program, the peak-flow data base, and the basin-characteristics data base. Dave R. Johnson is responsible for maintaining the State water-use data base.

\section{Support Units}

\section{AdmInlstrative Services Unlt}

The Administrative Services Unit is responsible for providing administrative support to the District Office, Field Headquarters, and project chiefs. Support services include administrative activities related to personnel matters; purchasing; contracting; office, warehouse, and laboratory space; vehicles; and fiscal accounting. Although the Unit does not have direct quality-assurance responsibilities for technical aspects of the District program, its role in managing project budgets; purchasing equipment and supplies; contracting for services; securing office, warehouse, and laboratory space; acquiring field vehicles; and other administrative duties is essential to the successful completion of projects. Mark S. Gerl, Administrative Officer and Chief of the Unit, monitors District, Field Headquarters, and project budgets and advises project chiefs and District managers of the fiscal status of projects.

\section{Computer Services Unlt}

The Computer Services Unit is responsible for providing computer support to the District and to project chiefs. Personnel assigned to the Unit operate and maintain the District computers and peripheral hardware. They provide technical support for the District's library of computer software, train staff on use and application of various software packages, write programs for various applications, and document software developed for District use. Although the Unit does not have direct quality-assurance responsibilities for technical aspects of the District program, its role in providing computer services is essential to the successful implementation and completion of District programs. The Unit is responsible for periodic duplication of District computer files and records to ensure minimal loss of information in the event of equipment failure or malfunction. Gary D. Rogers, Computer Specialist, is responsible for efficient operation and effective use of the District's computer hardware and software.

\section{Publications Unlt}

The Publications Unit is responsible for providing report preparation and processing services for the District. Personnel assigned to the Unit prepare text and illustrations from author's rough drafts, perform editorial reviews, arrange for technical colleague reviews, ensure adequate editorial, verification, and technical review and adequate author response to review comments, transmit reports for Director or Regional approval, prepare approved reports for publication, and distribute published reports. The Unit is involved in early phases of project planning and implementation. Unit personnel assist project chiefs in planning final report products, preparing report outlines, and acquiring base maps for final products. Timely completion of well-written, technically sound reports is a direct measure of the District's success in meeting quality-assurance guidelines. Consequently, the Publications Unit serves an essential and integral role in the District's quality-assurance efforts. Cynthia J. Harksen, Chief of the Unit, is responsible for ensuring that reports receive adequate editorial, verification, and technical reviews and that authors adequately respond to all review comments before the report is submitted for Director or Regional approval.

\section{Special Equipment Unit}

The Special Equipment Unit provides equipment and supply support to the District and Field Headquarters. The Unit is responsible for maintaining an inventory of equipment, parts, and supplies to meet routine needs for construction activities and maintenance of District equipment. Personnel assigned to the Unit repair and service digital and analog recorders, manometers, reels, wading rods, sampling devices, and 
other mechanical and electrical instruments and equipment. Timothy J. Morgan is responsible for inventorying controlled property and serving as a technical advisor on maintenance of data-collection instrumentation. Collection of reliable data requires the use of properly maintained and calibrated instruments. Consequently, the Unit serves an important role in meeting quality-assurance goals of the District.

\section{Discipline Speciallsts}

Discipline specialists serve as technical advisors to the Office of the District Chief. Although every discipline specialist has other primary duties, each contributes significantly to quality-assurance activities by virtue of individual special competencies in particular fields. The discipline specialists, individually and collectively, assist in program planning, project planning, design and implementation of data-collection programs, technical oversight of interpretive projects, and review of reports. The specialists are responsible for technical adequacy of programs in their particular field of expertise and serve as advisors to other members of the District staff. Project work plans and draft reports are reviewed by the specialists to ensure technical adequacy of methodology, appropriate application of methodologies, and validity of results and conclusions. The specialists and their area(s) of expertise are:

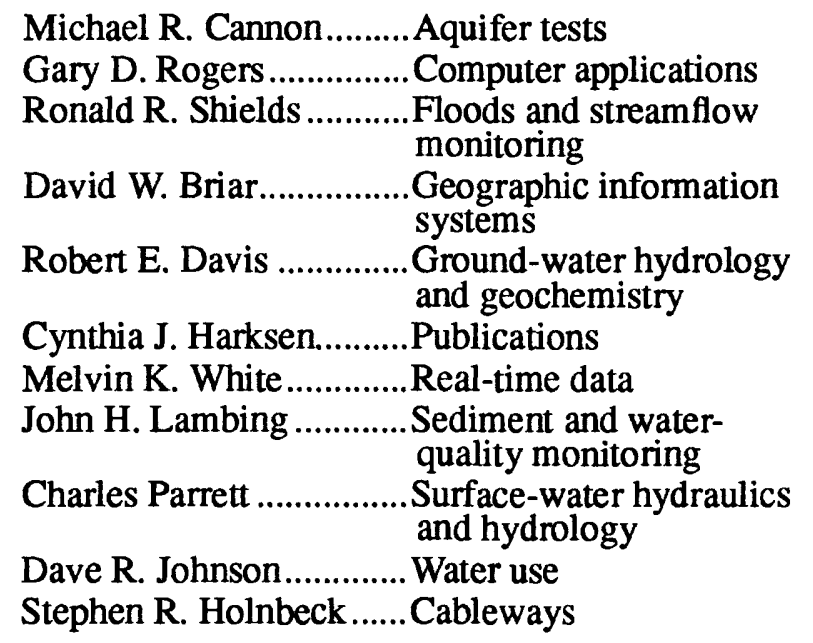

\section{Management Advisors}

Management advisors provide guidance on various personnel issues and support functions. The management advisors do not have quality-assurance responsibilities but provide advice and assistance that are essential to District management. The management advisors are:

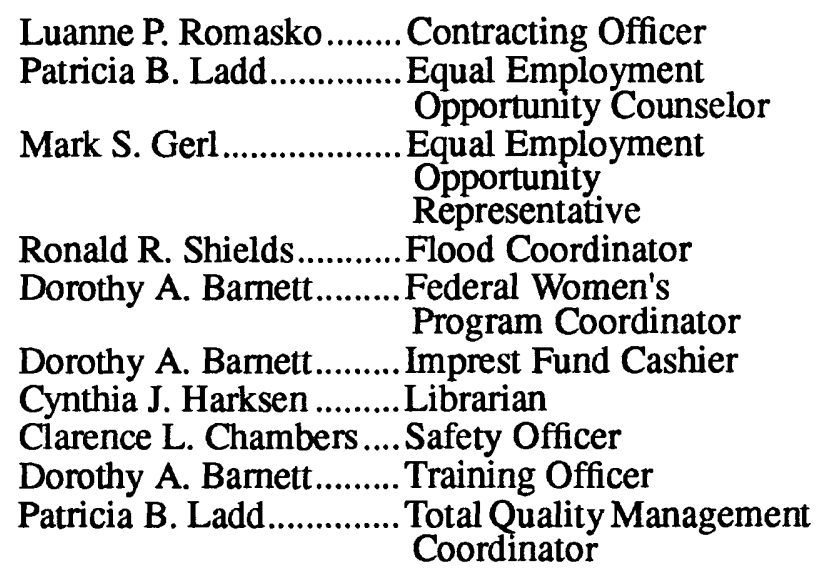

\section{QUALITY ASSURANCE}

\section{District Quality-Assurance Pollcy}

Maintaining the credibility and technical excellence of the U.S. Geological Survey's products is as much a function of attitude as adherence to written policy. An ethic of professionalism to conduct activities in a scientific, impartial, thorough, and meticulous manner will usually yield credible and valid results that are acceptable to most users and can be used as the basis for litigation or negotiations. In some instances, data or interpretive products might need to meet documented quality-assurance standards before being admissible in court proceedings. To meet this need, hydrologic work performed by or for the Montana District is designed to satisfy the District Quality-Assurance Policy:

\section{"The Montana District conducts all investigations in a manner that results in data of known quality, following the policies and technical directives of the U.S. Geological Survey, Water Resources Division."}

The quality of data is considered to be "known" when a U.S. Geological Survey approved and documented procedure is used to collect, process, or analyze the data. If work is performed for which no approved or documented procedure is applicable or available, adequate documentation is prepared to describe the precision and bias expected from the procedure used.

It is important to note that this quality-assurance policy does not always require use of the most accurate or precise methodology available. The methodology 
selected for a particular activity, however, is commensurate with the needs of the program, with consideration given to any constraints of funding, resources, and time available. The essential element is the requirement to define the precision and bias of the final product.

\section{District Functions and Quallty-Assurance Responsibilities}

The activities of the Montana District are systematically conducted under a hierarchy of supervision and management that is designed to ensure conformance with Division policy on quality assurance. The systematic approach guides the direction of work from program planning to ultimate completion of assignments. Activities undertaken by the District are expected to meet the quality-assurance requirements outlined in this report for the following functional elements: program planning, project planning, project implementation, equipment calibration and maintenance, data collection, data processing and storage, data analysis and interpretation, synthesis, water apportionment, reports preparation and processing, and training. Not all activities include every element, but all conform to the quality-assurance policies that are appropriate to successful completion of the activity.

\section{Program Planning}

QUALITY-ASSURANCE POLICY.--" Program plans are developed in accordance with the annual statement of program priorities issued by Headquarters. All program plans recognize the national interests served. Local and State interests are addressed to the extent that national perspectives and responsibilities are served."

The effective use of personnel and other resources, the maintenance of District viability, and the fulfillment of mission goals of the Bureau (U.S. Geological Survey) and Division require short- and longrange program planning. The District Chief has primary responsibility for this function but is assisted and advised by the senior staff and the discipline specialists. In addition to the District Chief, the senior staff includes the Assistant District Chief, the Chief of the Hydrologic Surveillance and Analysis Section, the Chief of the Hydrologic Investigations Section, and the Administrative Officer. The Chief of the Hydrologic Surveillance and Analysis Section ensures that datacollection sites operated by the District satisfy national, regional, and local needs. The Chief of the Hydrologic Investigations Section determines what hydrologic inventories, investigations, and research are needed to satisfy national, regional, and local needs for hydrologic information and analysis.

Discipline specialists exercise responsibility for program planning by advising the District Chief on matters related to their particular field of expertise. They provide substantive recommendations on stateof-the-art methodologies, resources required to implement various technologies or study approaches, technical adequacy of study plans, and the likelihood of successfully meeting study objectives with available resources.

National needs are dictated by Bureau and Division mission goals. Each year the Division identifies priority program thrusts that are to receive special attention. These topics are reviewed by the senior staff and discipline specialists to guide program development with local and other Federal cooperating agencies.

Regional and local priorities are usually determined in consultation with local, State, and other Federal agencies. The senior staff and discipline specialists regularly visit these agencies to maintain a current awareness of the priority issues of concern to them. When possible, regional and local priority concerns are considered in context with national priority goals established by Headquarters. Regional and local issues that are not directly related to national priority goals are considered if they can be addressed within the framework of the Bureau or Division mission. Hydrologic issues that are clearly outside the U.S. Geological Survey's mission are not addressed.

Project chiefs, Field Headquarters chiefs, and other members of the District staff are encouraged to discuss hydrologic programs with accredited cooperating agencies. No formal proposals are presented to potential cooperating agencies before review by the appropriate discipline specialists for technical adequacy and by the District Chief for conformance with U.S. Geological Survey mission goals.

Although the District does not prepare a formal long-range plan, it documents its intentions in an informal report, which is presented to the staff of the Office of the Regional Hydrologist at the annual program review meeting near the end of the third quarter of each fiscal year ${ }^{1}$. After review and approval by Region staff, program plans are developed into specific project proposals for consideration by cooperating agencies. After proposals receive approval from cooperating agencies and Region, written agreements are prepared to formalize the plans.

\footnotetext{
${ }^{1}$ A fiscal year is the 12-month period October 1 through September 30. It is designated by the calendar year in which it ends.
} 


\section{Project PlannIng}

QUALITY-ASSURANCE POLICY.--"Plans for new projects are developed in sufficient detail to allow adequate technical evaluation and review. Documentation of plans in project proposals is submitted to Region staff for review and acceptance before standard projectdescription forms are prepared for formal approval by Region."

Project planning--an important element of the District's overall quality-assurance plan--involves formulation, review, and approval of a formal project proposal that is used to guide the conduct of the project. The project proposal is a written documentation of the project plans, and the project proposal cover sheet serves as formal documentation of review and approval of the plan by reviewing personnel.

Contents of the project proposals can vary considerably depending on complexity and scope of the planned activity. However, all proposals are prepared in accordance with guidelines provided in Central Region Memorandum No. 79.16, which states:

"...a project proposal must contain sufficient information for its evaluation for acceptability and adequacy. Acceptability, in summary, means appropriateness of the project for WRD [Water Resources Division] undertaking, its relationship to regional or national issues, and our capability to undertake the work. Adequacy relates to the technical soundness of the proposal, the time allowed for completion, proposed report plans, the level of funding, and the proposed staffing."

As a minimum, project proposals contain a brief introductory section that outlines the need for the study; a concise statement of the project purpose; a description of the hydrologic conditions in the study area as they relate to the proposed work; a relatively detailed description of the plan of study including techniques or models to be used, data required to apply the methodology, modifications to existing models that might be required to apply the methodology to the project, and consultation with specialists; and a description of all intermediate and final reports to result from the study.

Project proposals are usually written by the project chief. If a project chief has not been selected, several individuals including discipline specialists, section chiefs, or other staff members independently or collaboratively prepare the proposal. The proposals are reviewed by the appropriate discipline specialists and the section chief for technical adequacy and compliance with Regional guidelines. After proposals have been reviewed and revised at the District level, formal approval from Region staff is requested. A cover sheet attached to the proposal serves as the official documentation that the District has concurred with the plan and that Region has approved the proposal.

\section{Project Implementation}

QUALITY-ASSURANCE POLICY.--"Projects are implemented in accordance with an approved work plan, which is developed and approved for each project. The time allotted for developing the work plan depends on the length and complexity of the project, but the plan is approved before any substantive work is undertaken. Any significant deviations from the work plan require that the original plan be modified and reapproved."

After a proposed project has been approved by Region staff and funding has been arranged with a cooperating agency, the project chief provides descriptive information for the project as outlined in the Maintain Project and Proposal module of the U.S. Geological Survey Administrative Information System. The descriptive information is submitted within 30 days of project proposal approval through the Administrative Officer and the District Chief to the Regional Hydrologist for approval. After formal approval of the project description, the project chief prepares a work plan for the project.

The work plan is an expansion of the formally approved project proposal and project description. Although the formally approved documents serve as the written expression of the planning process for quality-assurance purposes, the work plan serves as the day-to-day operational framework for completing the project. It contains specific information on methods to be used, data-collection plans, field schedules, equipment and laboratory needs, personnel requirements, and budget requirements. Most importantly, the plan contains a schedule of interim and final deadlines for various elements of the project. For most projects, the work plan describes report plans including types of products, table of contents, list of illustrations, list of tables, and list of references. Work plans may contain draft sections of the final report.

In developing various aspects of the work plan, the project chief collaborates with colleagues and consults with appropriate discipline specialists during technical review of specific elements. The project 
chief meets with the Chief of the Hydrologic Investigations Section and the Chief of the Publications Unit to discuss report plans, arrange for base maps, schedule report production services, and develop a conceptual plan for the final report. The work plan is approved by the Chief, Hydrologic Investigations Section before substantive work is undertaken.

Project chiefs meet at least quarterly with the Chief, Hydrologic Investigations Section to discuss progress, problems, plans, and modifications to the work plan. If appropriate, the project chief may orally describe the plans and progress to interested colleagues, District managers, discipline specialists, and cooperating agencies. The oral presentations are informal and discussion between the project chief and attendees is encouraged. Substantive suggestions are incorporated into the work plan to remedy identified deficiencies in methods, approach, data collection, analysis, or reports.

If, during development of the initial work plan or in subsequent reviews, the project chief or District managers determine that technology, funding, personnel, or time is inadequate to fulfill the objectives of the project, reasonable alternatives are developed for consideration by cooperating agencies. These agencies are advised throughout the course of the project about any deviations from the original proposal. Significant changes in methodology, time frame, personnel, or final report(s) are discussed and documented in a revised work plan.

\section{Equlpment Callbration and Malntenance}

QUALITY-ASSURANCE POLICY.--" Equipment and instruments used in hydrologic programs are maintained in serviceable condition and calibrated in accordance with guidelines documented in Division or District procedural guides or manufacturer instruction manuals."

Collection of hydrologic information onsite or in a laboratory involves the use of mechanical and electrical instruments that must be calibrated and maintained to ensure proper operation. Instructions, procedures, and quality-control practices are outlined in numerous field manuals, instructional guides, manufacturer's operating manuals, and District memorandums. All District employees who collect hydrologic measurements onsite or in a laboratory are responsible for proper maintenance of equipment in their care. Employees are required to read and practice guidelines for adjusting, calibrating, and testing instruments to ensure collection of reliable and accurate data. Unit and Field Headquarters chiefs are responsible for reviewing onsite and laboratory techniques of subordinates to ensure adherence to applicable guidelines. Chiefs prepare written statements documenting findings of reviews and submit these statements to the Chief, Hydrologic Surveillance and Analysis Section and the Chief, Hydrologic Investigations Section, who ensure that identified deficiencies are corrected.

All employees who measure specific conductance or $\mathrm{pH}$ in water samples are required to participate in the Division's National Field Quality Assurance Project by measuring and reporting these parameters for standard solutions provided by the project. Employees who fail to meet an acceptable level of accuracy in reported measurements receive additional training and are required to repeat the test to demonstrate an acceptable level of performance.

In addition to the responsibilities outlined above for employees and supervisors, the following individuals have specific responsibilities related to quality control of instruments and equipment:

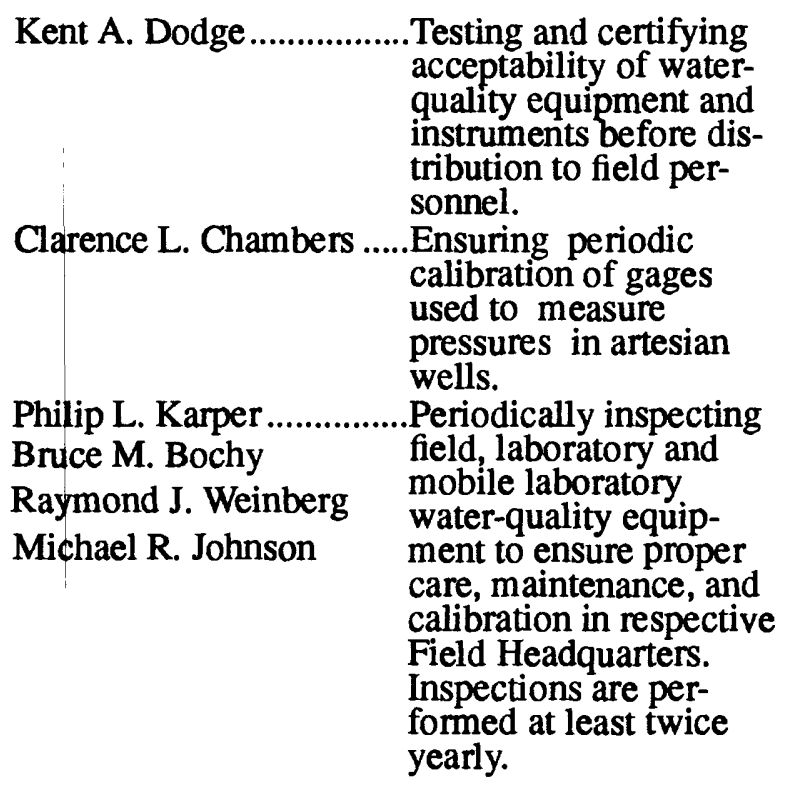

Instructions on procedures used to check and calibrate water-quality instruments are contained in the District field guide for water-quality activities (Knapton, 1985).

\section{Data Collection}

QUALITY-ASSURANCE POLICY.--"Data are collected using approved and documented procedures outlined in published Division or District technical manuals or reports. Any exceptions to the use of these procedures are documented in writing and approved by the District Chief." 
Routine data-collection activities of the U.S. Geological Survey are conducted with the goal of obtaining accurate, precise, and impartial observations. To attain this goal, data-collection activities are performed in strict accordance with approved methods. Techniques of Water Resources Investigations reports describe many of the field methods and procedures used in routine work. More specialized or non-standard procedures are documented in other U.S. Geological Survey report series or in professional journal articles.

In addition to guidelines in published reports, data-collection activities are governed by technical memorandums from Headquarters, Region, and District Offices. Each office is required to maintain a current file of technical memorandums describing field methods and to adopt those procedures when instructed. The Branch of Technical Development and Quality Systems maintains a file of all available technical and Division numbered memorandums.

During many hydrologic investigations, datacollection activities require non-standard and innovative procedures. As a scientific agency, the U.S. Geological Survey supports and encourages development of new methodologies. Investigators are encouraged to pursue new avenues of research and are rewarded for innovation and invention. However, new or modified procedures are documented and submitted to appropriate discipline specialists and section chiefs for review and comment prior to implementation. The non-standard techniques are outlined in project work plans, and innovative methods are described in reports.

When non-standard techniques are used, discipline specialists review the proposed plans to document the precision and bias of information collected. The data collected to document precision and bias of information are included in final reports.

Responsibility for ensuring compliance with data-collection policies ultimately lies with the District Chief. However, responsibility for reviewing datacollection activities, identifying deficiencies, and developing corrective measures has been delegated to the Chief of each operating section. Because data collection is basic to the successful accomplishment of the District's programs, chiefs of all Field Headquarters, operating section units, and projects are responsible for quality assurance of data collected by their respective staffs. Chiefs review day-to-day field operations of their offices, units, and projects to ensure an acceptable level of performance by field personnel. The chiefs execute their responsibilities by using acceptable management practices to identify and rectify deficiencies in employee training and performance to ensure that data- collection efforts result in acceptable products that meet quality-assurance criteria. When chiefs determine that corrective actions are required to remedy quality-assurance problems, they have full authority to take necessary action including remedial training, replication of work, or disciplinary measures. Substantive or recurring problems are reported to the Chief of the section for resolution.

In addition to the chiefs of the Field Headquarters, Lead Water-Quality Technicians assigned to each Field Headquarters have special quality-assurance responsibilities for water-quality data-collection activities. They review day-to-day water-quality datacollection activities of field personnel in their respective Field Headquarters. When they identify deficiencies that could result in non-compliance with qualityassurance standards, they advise the responsible individual of the deficiency and provide a written statement to the Field Headquarters chiefs for further review and corrective action. If the further review substantiates the deficiencies, the Field Headquarters chief advises the responsible individual of the problem and directs corrective measures to remedy the problem. Corrective measures may include recollection of samples, remedial training, or removal of data.

\section{Data Processing and Storage}

QUALITY-ASSURANCE POLICY.--" All hydrologic data collected by or for the District are reviewed and certified as meeting Division quality standards before entry into national data bases. Certified data are entered into appropriate data bases and made available for public use. Data that have not been reviewed and certified or that do not otherwise meet Division quality standards are released for public use only with an appropriate disclaimer."

After collection by adequately trained and supervised personnel using approved methods and properly calibrated and maintained equipment, data are processed, stored, and archived in accordance with Division and District guidelines. These procedures ensure integrity and prevent loss or damage to the data.

Primary records are generally field notes, recorder charts, laboratory reports, data from electronic recording or monitoring devices, and other forms of unedited data. The initial, unedited printed copy produced from various electronic data-recording systems is considered to be the primary record rather than the electronic media or computer file. 
Primary records are considered to be historic information and are stored permanently for future reference. Project files are maintained in the Hydrologic Investigations Section central files, information from wells and springs is stored in the statewide well-inventory file, information from streamflow-gaging stations is maintained in Field Headquarters files for the current year and the District central backfiles for previous years, and water-quality laboratory records are maintained in the District waterquality file. All primary records from hydrologic investigations are transferred to appropriate files at the conclusion of the project. Primary records are transferred to Federal archives if no immediate use for the information is anticipated. Archived records are carefully inventoried and cataloged to ensure that the records are retrievable.

Most hydrologic data collected by the District are processed by computer programs on the District's computer system. Proper use of computer programs is essential to maintain integrity of the data during processing for entry into computer data bases.

The principal hydrologic data bases maintained by the District are ADAPS (Automated Data Processing System), GWSI (Ground-Water Site Inventory), SWUDS (State Water Use Data System), and QWDATA (Water Quality Data Processing System). The following personnel maintain the District data bases and serve as technical advisors to users:

$$
\begin{aligned}
& \text { Melvin K. White ..........ADAPS } \\
& \text { Joanna N. Thamke ......GWSI } \\
& \text { Dave R. Johnson ......... SWUDS } \\
& \text { Patricia B. Ladd .......... QWDATA }
\end{aligned}
$$

Responsibility for certification of data for entry into national data bases or for release to the public is assigned to the chiefs of the various Sections or to individual discipline specialists. Responsibility for approving surface-water records is assigned to the Chief of the Hydrologic Surveillance and Analysis Section. Responsibility for approving surface-waterquality records is assigned to the Water-Quality Specialist. Responsibility for approving sediment data and records is assigned to the Sediment Specialist. Responsibility for approving ground-water data is assigned to Chief of the Hydrologic Investigations Section. If deficiencies are identified, the reviewer advises the responsible office or individual of the problem and requires recalculation of records to correct the problem.

Within the Hydrologic Surveillance and Analysis Section, the chiefs of the Field Headquarters are responsible for quality assurance of records computed by their respective staffs. The office chiefs execute their responsibilities by using acceptable management practices to identify and rectify deficiencies in employee training and performance to ensure that records-computation efforts result in acceptable products that meet quality-assurance criteria. When chiefs determine that corrective actions are required to remedy quality-assurance problems, they have full authority to take necessary action including remedial training, replication of computations, or disciplinary measures. Substantive or recurring problems are reported to the Chief of the Section for resolution.

District data bases are periodically uploaded to the national data bases. Frequency of updates depends upon the kinds of data, the status of review and certification, and the District workload. District policy is to keep national files as current as possible. Updates are made no later than 6 months after the end of the water year ${ }^{2}$.

District computer files are periodically duplicated to guard against loss or damage due to system failure. Complete duplication is made once a week, and incremental duplication is made daily.

\section{Data Analysis and Interpretation}

QUALITY-ASSURANCE POLICY.--"Data are analyzed and interpreted in accordance with procedures documented in Division technical reports or other citable references. Innovative or undocumented procedures may be used if the techniques are adequately described in the project work plan and are included in the final report."

Analysis and interpretation of data involve a broad spectrum of activities ranging from relatively straight-forward application of statistical programs to development of very complex, multi-discipline models of hydrologic systems. Scientific curiosity and innovative thinking are considered to be important attributes in selecting or developing effective methods to analyze and interpret data. Therefore, the District policy is designed to encourage research and development of new technologies by not limiting interpretive procedures to a standardized list. In general, any procedure that has been described in Division technical reports or has been published in a citable document is considered to be acceptable for use in the analysis and interpretation of data. If a published procedure is substantially modified or if an innovative procedure is proposed, the investigator is required to describe the procedure in the project work plan and to discuss the methodology in a

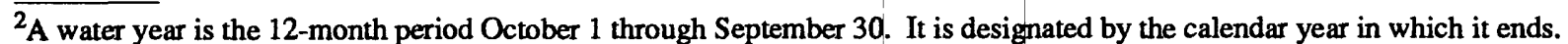


final report. The adequacy of the procedure is evaluated by the technical colleague-review process.

Each project chief is responsible for selecting the appropriate interpretive tools for use on assigned projects. The project chief searches the literature for citable documentation of the methods to be applied or prepares a detailed description of the technique for review by discipline specialists. The Chief of the Hydrologic Investigations Section is responsible for ensuring that appropriate technical review and approval are obtained before the investigation is begun. If District discipline specialists do not have the requisite expertise to review and approve the proposed methodology, outside assistance from Regional or Headquarters staff is solicited. The Chief of the Hydrologic Investigations Section approves or rejects proposed methodologies or techniques after review of recommendations or comments obtained from technical advisors. The decision is based on technical soundness of the methodology proposed and the resources available to perform the work.

Progress reviews are conducted quarterly to ensure that project personnel are using appropriate methods to analyze and interpret data. Reviews are conducted by the Chief of the Hydrologic Investigations Section and discipline specialists deemed appropriate for the project. In addition, periodic discipline reviews by Region and Headquarters personnel are conducted to ensure that District projects are performed in an acceptable manner by qualified and trained personnel.

\section{Synthesis}

QUALITY-ASSURANCE POLICY.--"Hydrologic information is synthesized in accordance with procedures documented in Division technical reports or other citable references. Innovative or undocumented procedures may be used if the techniques are adequately described in the project work plan and are included in the final report. All synthesized information is clearly differentiated from measured data."

For various reasons, the U.S. Geological Survey is sometimes asked to provide estimates of hydrologic information. In general, synthesized information is less accurate and less reliable than measured values, although some measurements may be difficult or impossible to obtain. U.S. Geological Survey policy allows for synthesis of hydrologic data but requires that such information be clearly identified and qualified. In some instances, policy permits synthesized information to be entered into national data bases and pub- lished in annual data reports. Other information, particularly that produced from model simulations, may be used in interpretive analysis but cannot be published or stored in data bases as estimated record.

Responsibility for approving inclusion of synthesized information in national data bases rests with the Chief, Hydrologic Surveillance and Analysis Section or the individual responsible for maintenance of the data base. The Chief or responsible individual may seek technical assistance from District, Region, or Headquarters discipline specialists in the review and approval of the synthesis technique used. No synthesized data are published or stored without adequate qualifying notation.

\section{Water Apportionment}

QUALITY-ASSURANCE POLICY.--"International waters are apportioned between Canada and the United States in accordance with the Boundary Waters Treaty of 1909, International Joint Commission Order of 1921, and procedures approved by the Accredited Officers for the St. Mary and Milk Rivers."

The District Chief is designated as the Field Representative for the Accredited Officer for the United States, St. Mary-Milk River Treaty. As Field Representative, the District Chief is responsible for reviewing and approving records for international streamflowgaging stations, approving computations of natural flows, and approving apportionment of flows in accordance with applicable treaties, guidance documents, and procedures manuals.

International streamflow-gaging stations on rivers, creeks, and canals and reservoir-stage stations are operated by the International Waters Section in cooperation with the Water Survey of Canada. Operation of streamflow-gaging stations and computation of streamflow records may require procedures different from those normally used by the U.S. Geological Survey. Because the records are produced jointly by the United States and Canada, some compromise may be required to satisfy the special needs of each Nation. The chief of the International Waters Section is responsible for negotiating acceptable resolutions to differences in methodology between the two countries. Activities of the International Waters Section are reported periodically to the Accredited Officer for the United States, St. Mary-Milk River Treaty. The reports describe unusual flow conditions, excess or deficit deliveries of water between the two countries, and any significant events related to apportionment activities. The Field Representative, the chief of the International Waters Section, 
and all personnel assigned to the Section meet annually with Canadian counterparts to review and approve records, to discuss mutual concerns, to resolve differences in procedures, to plan field schedules, and to review drafts of the annual report to the International Joint Commission.

\section{Reports Preparation and Processing}

QUALITY-ASSURANCE POLICY.--" Reports prepared by the Montana District are processed in accordance with Division and District publication guidelines. Interpretive reports must meet Division and Region technical, editorial, mechanical, and policy requirements before transmittal for Director or Region approval."

Reports are one of the Division's most important products. They provide a tangible measure of our productivity and inform the public of our findings. A properly written report describes procedures that are used to reach conclusions and, as such, serves as the written documentation of the quality-assurance efforts used in the project or program.

All interpretive reports prepared by the Division must be approved by the Director of the U.S. Geological Survey, or the Director's designee, before they are released to the public. Before a report is submitted for Director's approval, it passes through a rigorous review system designed to ensure technical adequacy and editorial quality. The District Chief ensures that all reports meet requirements for approval before transmittal for Director's approval.

The District Chief has been delegated the authority to approve noninterpretive reports. Approval is granted if the reports meet all the requirements for technical adequacy, internal consistency, editorial quality, and policy criteria. The District Chief ensures that District-approved reports do not contain interpretive material or analysis that would require a higher level of approval for release.

Detailed guidelines for preparing and processing reports are contained in Division publications and memorandums. These guidelines provide specific instructions and requirements for text, illustrations, and tables. Every author is required to read and follow the guidelines.

Report production begins at the earliest stages of the project with the development of a report outline, lists of proposed illustrations and tables, and preparation of the introductory section of the report. The text is written and illustrations and tables are prepared as components of the study are completed. Generally, the final report is in draft form at least 6 months before the scheduled end of the project to allow adequate time for report processing and approval. Anticipated deviations from the stated deadline for completion of draft reports is reported by the project chief to the Chief, Hydrologic Investigations Section at least 3 months before the scheduled due date of the draft report to allow time to rectify scheduling problems or modify deadlines.

The policy of the Division places the primary responsibility for report acceptability on the author. However, several individuals have responsibility to assist the author in meeting the assigned task of preparing technically sound and editorially correct manuscripts, Colleague reviewers are responsible for careful and thorough review of the report to identify any problems with technical content. The Chief of the Publications Unit is responsible for ensuring that report packages are ready for Director's approval. If any problems are noted in editorial, verification, or technical review or if any deficiencies are noted in author's responses to review comments, the Chief of the Publications Unit notifies the senior author in writing. A copy of the notice is provided to the Chief of the Hydrologic Investigations Section, who verifies the completion of required actions. The Chief of the Hydrologic Investigations Section is also responsible for ensuring that reviews are adequate and that author responses are appropriate. The District Chief is responsible for ensuring that all participants in the review process perform their duties adequately.

Because the District has been granted Fast Track report-processing privileges, some reports may be submitted directly to Headquarters for approval. The District Chief is responsible for ensuring that reports selected for Fast Track processing meet established Division criteria before transmittal to Headquarters for approval.

\section{Training}

QUALITY-ASSURANCE POLICY.--"Montana District employees receive adequate training to perform their assigned tasks."

Training is an integral part of the District's quality-assurance program. Employees are not assigned tasks for which they are not adequately trained. The responsibility for ensuring that employees are adequately trained is shared jointly by the employee, the employee's supervisor or unit chief, the discipline specialists, the District Training Officer, and the senior staff.

A formal training plan is prepared for each employee as part of the employee's Career Documentation Profile. The employee is expected to participate in 
development of the training plan by identifying training needs and topics of personal interest. The employee's supervisor or unit chief discusses training needs with the employee during the annual performance appraisal process and documents training needs. The District Training Officer compiles a list of employee training needs and requests consideration by the District Chief. The District Chief and the senior staff make selections for training by weighing program plans, employee skills, and project requirements against funds available to support training activities.

The District considers workshops, conferences, National Training Center courses, correspondence courses, university courses, and in-house discipline seminars as formal training. All formal training is recognized and entered into the employee's Career Documentation Profile and other personnel records. Training records are updated within 5 days of completion of training. Employees are responsible for updating their own Career Documentation Profiles.

Although each employee is encouraged to document on-the-job experience in the autobiographical part of the Career Documentation Profile, work-related experience is normally not recognized as formal training. On-the-job training is generally provided by project chiefs, senior staff members, or discipline specialists. Supervisors or unit chiefs identify employee skill deficiencies and arrange on-the-job training to remedy any identified lack of training.

Allocation of funds to support training activities is the responsibility of the District Chief. Decisions on employee training are made on the basis of recommendations from supervisors, requests from employees, and availability of funds.

\section{SUMMARY}

The mission of the Water Resources Division of the U.S. Geological Survey is to provide the hydrologic information and understanding needed for the optimum utilization and management of the Nation's water resources for the overall benefit of the people of the United States. As the Nation's principal earth-science information agency, the U.S. Geological Survey has developed a worldwide reputation for collecting accurate data and producing factual, impartial data and interpretive reports. To ensure continued confidence in its products, the Water Resources Division has implemented a policy to ensure that all scientific work performed by or for the Division is conducted in accordance with a centrally managed quality-assurance program. As a part of that program, each District office is required to prepare a written District QualityAssurance Plan. This report establishes and documents a formal policy for quality assurance within the Montana District. Quality assurance is formalized by describing District organization and operational responsibilities, documenting the District qualityassurance policy, and describing District functions and the quality-assurance responsibilities for performing those functions.

The District quality-assurance plan does not describe detailed technical activities that are commonly termed "quality-control procedures." Instead, it focuses on policies, functions, and responsibilities that are implemented at the management level. Contents of the plan are reviewed annually and updated as personnel and programs change.

The District conducts its work through offices in Helena, Billings, Kalispell, and Fort Peck. Hydrologic data-collection programs and interpretive studies are conducted by three operating sections and four support units. The operating sections are responsible for implementation and execution of District projects, and the support units provide services and advice. Discipline specialists provide technical advice and assistance to the District and to chiefs of various projects. Management advisors provide guidance on various personnel issues and support functions.

Hydrologic work performed by and for the Montana District is required to satisfy the District QualityAssurance Policy, which states that all investigations are conducted in a manner that results in data of known quality, following the policies and technical directives of the U.S. Geological Survey, Water Resources Division. That policy is supported by a series of policy statements that describe responsibilities for specific functional elements of the District's program. The functional elements described are program planning, project planning, project implementation, equipment calibration and maintenance, data collection, data processing and storage, data analysis and interpretation, synthesis, water apportionment, reports preparation and processing, and training. Not all activities include every element, but all conform to the quality-assurance policies that are appropriate to successful completion of the activity.

\section{SELECTED REFERENCES}

Alt, D.F., and Iseri, K.T., 1986, Water Resources Division publications guide, Volume 1, Publications policy and text preparation: U.S. Geological Survey Open-File Report 87-205, 429 p.

American Public Health Association and others, 1989, Standard methods for the examination of water and wastewater (17th ed.): Washington, American Public Health Association, $1,526 \mathrm{p}$. 
Bennett, G.D., and Patten, E.P., Jr., 1960, Borehole geophysical methods for analyzing specific capacity of multiaquifer wells: U.S. Geological Survey Water-Supply Paper 1536-A, 25 p.

1962, Constant-head pumping test of a multiaquifer well to determine characteristics of individual aquifers: U.S. Geological Survey Water-Supply Paper 1536-G, p. 181-203.

Benson, M.A., and Dalrymple, Tate, 1967, General field and office procedures for indirect discharge measurements: U.S. Geological Survey Techniques of WaterResources Investigations, Book 3, Chapter A1, 30 p.

Bentall, Ray, compiler, 1963a, Methods of collecting and interpreting ground-water data: U.S. Geological Survey Water-Supply Paper 1544-H, 97 p.

$1963 \mathrm{~b}$, Methods of determining permeability, transmissibility, and drawdown: U.S. Geological Survey Water-Supply Paper 1536-I, p. 243-341.

1963c, Shortcuts and special problems in aquifer tests: U.S. Geological Survey Water-Supply Paper 1545-C, $117 \mathrm{p}$.

Bigelow, D.S., and Dossett, S.R., 1988, Instruction manual NADP/NTN site operation, National Atmospheric Deposition Program: Fort Collins, Colorado State University, Natural Resource Ecology Laboratory, 103 p.

Bishop, E.E., Eckel, E.B., and others, 1978, Suggestions to authors of the reports of the United States Geological Survey (6th ed.): Washington, U.S. Government Printing Office, $273 \mathrm{p}$.

Bodhaine, G.L., 1968, Measurement of peak discharge at culverts by indirect methods: U.S. Geological Survey Techniques of Water-Resources Investigations, Book 3, Chapter A3, $60 \mathrm{p}$.

Britton, L.J., and Greeson, P.E., eds., 1989, Methods for collection and analysis of aquatic biological and microbiological samples: U.S. Geological Survey Techniques of Water-Resources Investigations, Book 5, Chapter A4, $363 \mathrm{p}$.

Buchanan, T.J., and Somers, W.P., 1968, Stage measurement at gaging stations: U.S. Geological Survey Techniques of Water-Resources Investigations, Book 3, Chapter A7, 28 p.

1969, Discharge measurement at gaging stations: U.S. Geological Survey Techniques of Water-Resources Investigations, Book 3, Chapter A8, 65 p.

Carter, R.W., and Davidian, Jacob, 1968, General procedure for gaging streams: U.S. Geological Survey Techniques of Water-Resources Investigations, Book 3, Chapter A6, 13 p.

Claassen, H.C., 1982, Guidelines and techniques for obtaining water samples that accurately represent the water chemistry of an aquifer. U.S. Geological Survey OpenFile Report 82-1024, 49 p.
Cooper, H.H., Jr., Bredehoeft, J.D., and Papadopulos, I.S., 1967, Response of a finite-diameter well to an instantaneous charge of water: Water Resources Research, v. 3, no. 1, p. 263-269.

Cooper, H.H., Jr., Kohout, F.A., Henry, H.R., and Glover, R.E., 1964, Sea water in coastal aquifers: U.S. Geological Survey Water-Supply Paper 1613-C, 84 p.

Cooper, H.H., Jr., and Rorabaugh, M.I., 1963, Ground-water movements and bank storage due to flood stages in surface streams: U.S. Geological Survey Water-Supply Paper 1536-J, p. 343-366.

Corbett, D.M., and others, 1943, Stream-gaging procedure, a manual describing methods and practices of the Geological Survey: U.S. Geological Survey Water-Supply Paper 888, 245 p.

Craig, J.D., 1983, Installation and service manual for U.S. Geological Survey manometers: U.S. Geological Survey Techniques of Water-Resources Investigations, Book 8, Chapter A2, $57 \mathrm{p}$.

Dalrymple, Tate, and Benson, M.A., 1967, Measurement of peak discharge by the slope-area method: U.S. Geological Survey Techniques of Water-Resources Investigations, Book 3, Chapter A2, 12 p.

Davidian, Jacob, 1984, Computation of water-surface profiles in open channels: U.S. Geological Survey Techniques of Water-Resources Investigations, Book 3, Chapter A15, $48 \mathrm{p}$.

Dempster, G.R., Jr., compiler, 1990, National Water Information System user's manual, volume 2, chapter 3-Automated data processing system: U.S. Geological Survey Open-File Report 90-116, 344 p.

Durbin, T.J., 1978, Calibration of a mathematical model of the Antelope Valley ground-water basin, California: U.S. Geological Survey Water-Supply Paper 2046, $51 \mathrm{p}$.

Federal Inter-Agency Sedimentation Project, 1981, A study of methods used in measurement and analysis of sediment loads in streams; catalog, instruments and reports for fluvial sediment investigations: Minneapolis, Minn., St. Anthony Falls Hydraulic Laboratory, 134 p.

Ferris, J.G., Knowles, D.B., Brown, R.H., and Stallman, R.W., 1962, Theory of aquifer tests: U.S. Geological Survey Water-Supply Paper 1536-E, p. 69-174.

Fishman, M.J., and Friedman, L.C., eds., 1989, Methods for determination of inorganic substances in water and fluvial sediments: U.S. Geological Survey Techniques of Water-Resources Investigations, Book 5, Chapter A1, $545 \mathrm{p}$.

Friedman, L.C., and Erdman, D.E., 1982, Quality assurance practices for the chemical and biological analyses of water and fluvial sediments: U.S. Geological Survey Techniques of Water-Resources Investigations, Book 5 , Chapter A6, 181 p. 
Garber, M.S., and Koopman, F.C., 1968, Methods of measuring water levels in deep wells: U.S. Geological Survey Techniques of Water-Resources Investigations, Book 8, Chapter A1, 23 p.

Gordon, A.B., and Katzenbach, Max, 1983, Guidelines for use of water quality monitors: U.S. Geological Survey Open-File Report 83-681, 94 p.

Grove, D.B., 1976, A model for calculating effects of liquid waste disposal in deep saline aquifers: U.S. Geological Survey Water-Resources Investigations Report 76-61, $265 \mathrm{p}$.

1979, Revision of the documentation for a model for calculating effects of liquid waste disposal in deep saline aquifers: U.S. Geological Survey WaterResources Investigations Report 79-96, $72 \mathrm{p}$.

Guy, H.P., 1969, Laboratory theory and methods for sediment analysis: U.S. Geological Survey Techniques of Water-Resources Investigations, Book 5, Chapter C1, $58 \mathrm{p}$.

1970, Fluvial sediment concepts: U.S. Geological Survey Techniques of Water-Resources Investigations, Book 3, Chapter C1, 55 p.

Guy, H.P., and Norman, V.W., 1970, Field methods for measurement of fluvial sediment: U.S. Geological Survey Techniques of Water-Resources Investigations, Book 3, Chapter C2, 59 p.

Hem, J.D., 1985, Study and interpretation of the chemical characteristics of natural water (3d ed.): U.S. Geological Survey Water-Supply Paper 2254, 263 p.

Hubbert, M.K., 1940, The theory of ground-water motion: Journal of Geology, v. 48, no. 8, pt. 1, p. 785-944.

Hulsing, Harry, 1967, Measurement of peak discharge at dams by indirect methods: U.S. Geological Survey Techniques of Water-Resources Investigations, Book 3, Chapter A5, 29 p.

Hutchison, N.E., 1975, WATSTORE [National Water Data Storage and Retrieval System of the U.S. Geological Survey] user's guide: U.S. Geological Survey OpenFile Report 75-426, 791 p.

Janzer, V.J., 1985, The use of natural waters as U.S. Geological Survey reference samples: Philadelphia, American Society for Testing and Materials, Special Technical Publication 867, p. 319-333.

Jenkins, C.T., 1970, Computation of rate and volume of stream depletion by wells: U.S. Geological Survey Techniques of Water-Resources Investigations, Book 4, Chapter D1, 17 p.

Johnson, A.I., 1963, A field method for measurement of infiltration: U.S. Geological Survey Water-Supply Paper 1544-F, 27 p.

Johnson, P.W., White, N.D., and Page, H.G., 1962, Geologic and hydrologic aspects of test-well drilling: U.S. Geological Survey Open-File Report 62-161, 118 p.
Jorgensen, D.G., 1980, Relationships between basic soilsengineering equations and basic ground-water flow equations: U.S. Geological Survey Water-Supply Paper 2064, 40 p.

Kennedy, E.J., 1983, Computation of continuous records of streamflow: U.S. Geological Survey Techniques of Water-Resources Investigations, Book 3, Chapter A13, $53 \mathrm{p}$.

1984, Discharge ratings at gaging stations: U.S. Geological Survey Techniques of Water-Resources Investigations, Book 3, Chapter A10, 59 p.

1990, Levels at streamflow-gaging stations: U.S. Geological Survey Techniques of Water-Resources Investigations, Book 3, Chapter A19, 27 p.

Keys, W.S., and MacCary, L.M., 1971, Application of borehole geophysics to water-resources investigations: U.S. Geological Survey Techniques of Water-Resources Investigations, Book 2, Chapter E1, $126 \mathrm{p}$.

Kilpatrick, F.A., and Cobb, E.D., 1985, Measurement of discharge using tracers: U.S. Geological Survey Techniques of Water-Resources Investigations, Book 3, Chapter A16, $52 \mathrm{p}$.

Kilpatrick, F.A., Condes de la Torres, Alberto, and Hutchinson, R.D., 1983, An assessment of collection and analysis of hydrologic data by private contractors for the U.S. Geological Survey: U.S. Geological Survey Water-Resources Investigations Report 83-4104, 132 p.

Kilpatrick, F.A., and Schneider, V.R., 1983, Use of flumes in measuring discharge: U.S. Geological Survey Techniques of Water-Resources Investigations, Book 3, Chapter A14, $46 \mathrm{p}$.

Kilpatrick, F.A., and Wilson, J.F., Jr., 1989, Measurement of time of travel in streams by dye tracing: U.S. Geological Survey Techniques of Water-Resources Investigations, Book 3, Chapter A9, 27 p.

Knapton, J.R., 1985, Field guidelines for collection, treatment, and analysis of water samples, Montana District: U.S. Geological Survey Open-File Report 85-409, 86 p.

Knapton, J.R., and Nimick, D.A., 1991, Quality assurance for water-quality activities of the U.S. Geological Survey in Montana: U.S. Geological Survey Open-File Report 91-216, 41 p.

Konikow, L.F., 1977, Modeling chloride movement in the alluvial aquifer at the Rocky Mountain Arsenal, Colorado: U.S. Geological Survey Water-Supply Paper 2044, 43 p.

Konikow, L.F., and Bredehoeft, J.D., 1978, Computer model of two-dimensional solute transport and dispersion in ground water: U.S. Geological Survey Techniques of Water-Resources Investigations, Book 7, Chapter C2, $90 \mathrm{p}$. 
Koopman, F.C., 1979, Downhole pumps for water sampling in small-diameter wells: U.S. Geological Survey OpenFile Report 79-1264, 67 p.

Laenen, Antonius, 1985, Acoustic velocity meter systems: U.S. Geological Survey Techniques of WaterResources Investigations, Book 3, Chapter A17, 38 p.

Lambing, J.H., and Dodge, K.A., 1993, Quality assurance for laboratory assurance of suspended-sediment samples by the U.S. Geological Survey in Montana: U.S. Geological Survey Open-File Report 93-131, 34 p.

Larson, S.P., 1978, Direct solution algorithm for the twodimensional ground-water flow model: U.S. Geological Survey Open-File Report 79-202, 22 p.

Lofgren, B.E., 1968, Analysis of stresses causing land subsidence, in Geological Survey Research 1968: U.S. Geological Survey Professional Paper 600-B, p. B219B225.

Lohman, S.W., 1972, Ground-water hydraulics: U.S. Geological Survey Professional Paper 708, $70 \mathrm{p}$.

Lusczynski, N.J., 1961, Filter-press method of extracting water samples for chloride analysis: U.S. Geological Survey Water-Supply Paper 1544-A, p. A1-A8.

MacCary, L.M., 1980, Use of geophysical logs to estimate water-quality trends in carbonate aquifers: U.S. Geological Survey Water-Resources Investigations Report $80-57,23 \mathrm{p}$.

Matthai, H.J., 1967, Measurement of peak discharge at width contractions by indirect methods: U.S. Geological Survey Techniques of Water-Resources Investigations, Book 3, Chapter A4, 44 p.

Meyer, W.R., 1962, Use of a neutron moisture probe to determine the storage coefficient of an unconfined aquifer, in Short papers in geology, hydrology, and topography: U.S. Geological Survey Professional Paper 450-E, p. E174-E176.

Papadopulos, I.S., 1963, Preparation of type curves for calculating $\mathrm{T} / \mathrm{S}$ of a wedge-shaped aquifer, in Short papers in geology and hydrology: U.S. Geological Survey Professional Paper 475-B, p. B196-B 198.

Pinder, G.F., Bredehoeft, J.D., and Cooper, H.H., Jr., 1969, Determination of aquifer diffusivity from aquifer response to fluctuations in river stage: Water Resources Research, v. 5, no. 4, p. 850-855.

Poland, J.F., Lofgren, B.E., Ireland, R.L., and Pugh, R.G., 1975, Land subsidence in the San Joaquin Valley, California, as of 1972: U.S. Geological Survey Professional Paper 437-H, 78 p.

Porterfield, George, 1972, Computation of fluvial-sediment discharge: U.S. Geological Survey Techniques of Water-Resources Investigations, Book 3, Chapter C3, $66 \mathrm{p}$.

Prill, R.C., and Aronson, D.A., 1978, Ponding-test procedure for assessing the infiltration capacity of storm-water basins, Nassau County, New York: U.S. Geological Survey Water-Supply Paper 2049, 29 p.

Pritt, Jeffrey, and Jones, B.E., 1989, eds., 1990 National Water Quality Laboratory services catalog: U.S. Geological Survey Open-File Report 89-386, looseleaf.

Rantz, S.E., and others, 1982a, Measurement of stage and discharge, Volume 1 of Measurement and computation of streamflow: U.S. Geological Survey Water-Supply 2175, p. 1-284.

1982b, Computation of discharge, Volume 2 of Measurement and computation of streamflow: U.S. Geological Survey Water-Supply Paper 2175, p. 285-631.

Reed, J.E., 1980, Type curves for selected problems of flow to wells in confined aquifers: U.S. Geological Survey Techniques of Water-Resources Investigations, Book 3, Chapter B3, $106 \mathrm{p}$.

Remson, Irwin, McNeary, S.S., and Randolph, J.R., 1961, Water levels near a well discharging from an unconfined aquifer: U.S. Geological Survey Water-Supply Paper 1536-B, $39 \mathrm{p}$.

Riggs, H.C., 1968a, Frequency curves: U.S. Geological Survey Techniques of Water-Resources Investigations, Book 4, Chapter A2, 15 p.

1968b, Some statistical tools in hydrology: U.S. Geological Survey Techniques of Water-Resources Investigations, Book 4, Chapter A1, $39 \mathrm{p}$.

1972, Low-flow investigations: U.S. Geological Survey Techniques of Water-Resources Investigations, Book 4, Chapter B1, $18 \mathrm{p}$.

1973, Regional analyses of streamflow characteristics: U.S. Geological Survey Techniques of WaterResources Investigations, Book 4, Chapter B3, 15 p.

Riggs, H.C., and Hardison, C.H., 1973, Storage analyses for water supply: U.S. Geological Survey Techniques of Water-Resources Investigations, Book 4, Chapter B2, $20 \mathrm{p}$.

Schaffranek, R.W., Baltzer, R.A., and Goldberg, D.E., 1981, A model for simulation of flow in singular and interconnected channels: U.S. Geological Survey Techniques of Water-Resources Investigations, Book 7, Chapter C3, $110 \mathrm{p}$.

Schneider, Robert, 1962, An application of thermometry to the study of ground water: U.S. Geological Survey Water-Supply Paper 1544-B, 16 p.

Shuter, Eugene, and Johnson, A.I., 1961, Evaluation of equipment for measurement of water level in wells of small diameter: U.S. Geological Survey Circular 453, $12 \mathrm{p}$.

Skibitzke, H.E., and da Costa, J.A., 1962, The ground-water flow system in the Snake River Plain, Idaho--An idealized analysis: U.S. Geological Survey Water-Supply Paper 1536-D, 67 p.

Smoot, G.F., and Novak, C.E., 1968, Calibration and maintenance of vertical-axis type current meters: U.S. Geo- 
logical Survey Techniques of Water-Resources Investigations, Book 8 , Chapter $\mathrm{B} 2,15 \mathrm{p}$.

1969, Measurement of discharge by the moving-boat method: U.S. Geological Survey Techniques of WaterResources Investigations, Book 3, Chapter A11, 22 p.

Sorey, M.L., 1978, Numerical modeling of liquid geothermal systems: U.S. Geological Survey Professional Paper 1044-D, 25 p.

Stallman, R.W., 1963, Electric analog of three-dimensional flow to wells and its application to unconfined aquifers: U.S. Geological Survey Water-Supply Paper 1536-H, p. 205-242.

1964 , Multiphase fluids in porous media--A review of theories pertinent to hydrologic studies: U.S. Geological Survey Professional Paper 411-E, $51 \mathrm{p}$.

1971, Aquifer-test design, observation, and data analysis: U.S. Geological Survey Techniques of WaterResources Investigations, Book 3, Chapter B 1, 26 p.

Stallman, R.W., and Papadopulos, I.S., 1966, Measurement of hydraulic diffusivity of wedge-shaped aquifers drained by streams: U.S. Geological Survey Professional Paper 514, $50 \mathrm{p}$.

Stevens, H.H., Jr., Ficke, J.F., and Smoot, G.F., 1975, Water temperature--Influential factors, field measurement, and data presentation: U.S. Geological Survey Techniques of Water-Resources Investigations, Book 1, Chapter D1, $65 \mathrm{p}$.

Thatcher, L.L., Janzer, V.J., and Edwards, K.W., 1977, Methods for determination of radioactive substances in water and fluvial sediments: U.S. Geological Survey Techniques of Water-Resources Investigations, Book 5, Chapter A5, $95 \mathrm{p}$.

Trescott, P.C., 1976, Documentation of finite-difference model for simulation of three-dimensional groundwater flow: U.S. Geological Survey Open-File Report 75-438, $30 \mathrm{p}$.

Trescott, P.C., and Larson, S.P., 1976, Documentation of finite-difference model for simulation of threedimensional ground-water flow: U.S. Geological Survey Open-File Report 76-591, 20 p.

Trescott, P.C., Pinder, G.F., and Larson, S.P., 1976, Finite difference model for aquifer simulation in two dimensions with results of numerical experiments: U.S. Geological Survey Techniques of Water-Resources Investigations, Book 7, Chapter $\mathrm{C} 1,116 \mathrm{p}$.
U.S. Department of the Interior, 1977, National handbook of recommended methods for water-data acquisition, Chapters 2, 3, 4, 5: U.S. Geological Survey, Office of Water Data Coordination, looseleaf.

U.S. Environmental Protection Agency, 1986, Quality criteria for water, 1986: EPA 440/5-86-001, unpaged.

U.S. Geological Survey, 1985, Procedural guide for international gauging stations on boundary waters between Canada and the United States of America: U.S. Geological Survey Open-File Report 85-329, 105 p.

issued annually, Water resources data, Montana: U.S. Geological Survey water-data report.

U.S. Government Printing Office, 1984, Style manual: Washington, D.C., 479 p.

Weeks, E.P., and Sorey, M.L., 1973, Use of finite-difference arrays of observation wells to estimate evapotranspiration from ground water in the Arkansas River valley, Colorado: U.S. Geological Survey Water-Supply Paper 2029-C, 27 p.

Wershaw, R.L., Fishman, M.J., Grabbe, R.R., and Lowe, L.E., eds., 1987, Methods for the determination of organic substances in water and fluvial sediments: U.S. Geological Survey Techniques of Water-Resources Investigations, Book 5, Chapter A3,80 p.

Wilson, J.F., Jr., Cobb, E.D., and Kilpatrick, F.A., 1986, Fluorometric procedures for dye tracing: U.S. Geological Survey Techniques of Water-Resources Investigations, Book 3, Chapter A12, 34 p.

Wood, W.A., 1976, Guidelines for collection and field analysis of ground-water samples for selected unstable constituents: U.S. Geological Survey Techniques of Water-Resources Investigations, Book 1, Chapter D2, $24 \mathrm{p}$.

Wyrick, G.G., and Floyd, E.O., 1961, Microtime measurements in aquifer tests on open-hole artesian wells: U.S. Geological Survey Water-Supply Paper 1545-A, 11 p.

Zody, A.A.R., Eaton, G.P., and Mabey, D.R., 1974, Application of surface geophysics to ground-water investigations: U.S. Geological Survey Techniques of WaterResources Investigations, Book 2, Chapter D1, $116 \mathrm{p}$. 